УДК 552.143

\title{
МОДЕЛИРОВАНИЕ ГЕОЛОГИЧЕСКОГО СТРОЕНИЯ ПРОДУКТИВНЫХ ОТЛОЖЕНИЙ вИКУЛОВСКОЙ СВИТЫ
}

\author{
Казанская Диана Андреевна', \\ trinity0077@mail.ru
}

\author{
Александров Вадим Михайлович ${ }^{1,2}$, \\ alexandrov_v@aotandem.ru \\ Белкина Валентина Александровна', \\ belkinava@tyuiu.ru

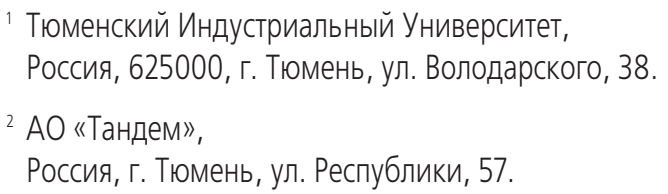

Актуальность. Задачи поисков, разведки, оценки ресурсов и запасов, проектирования, разработки решаются на основе геологических моделей. Наряду с тем, что современное геологическое моделирование позволяет получить трехмерное описание строения геологического объекта, изучить характер и изменчивость параметров пласта и насыщающих его флюидов, оно также позволяет оценить неопределенности, неизбежно возникающие при моделировании геологического строения пласта. Из этого следует, что точность решения любой геологической задачи в существенной степени определяется адекватностью трехмерной модели соответствующего объекта. Таким образом, появляется необходимость привлечения для построения моделей, кроме эмпирических данных, всех видов априорной и косвенной информации - в частности, концептуальной седиментологической модели.

Цель: усовершенствование методики построения трёхмерных геологических моделей, учитывающей особенности условий седиментации. Это обусловлено тем, что именно литофациальные характеристики продуктивных отложений являются основными факторами неоднородности природных резервуаров и нефтенасыщенности пород-коллекторов. Методика, учитывающая фациальное строение залежей, позволяет построить дискретно-непрерывную трехмерную модель, более адекватно описывающую изучаемый геологический объект и обладающую заметно более высокими прогностическими свойствами.

Объекты: продуктивные пласты викуловской свиты Ем-Еговского лицензионного участка.

Методы: детальная корреляция, усовершенствованная электрометрическая методика фациальной диагностики отложений, детерминистические и стохастические методы двухмерного и трехмерного моделирования геологических параметров.

Результаты. По данным керна и материалов геофизических исследований скважин с использованием усовершенствованной методики В.С. Муромцева построена фациальная модель, включающая следующие группы фаций горизонта ВК, викуловской свиты: дальняя зона пляжа, переходная зона пляжа и предфронтальная зона пляжа. С учётом данных по вновь пробуренным 192 скважинам проведена детальная корреляция горизонта ВК. По её результатам внутри пласта ВК, выделено три седиментационных цикла, для которых характерна довольно хорошая выдержанность по площади. На основе более точных данных сейсмики и данных 192 вновь пробуренных скважин с использованием концептуальной модели обстановок седиментации создана уточнённая модель залежи горизонта ВК, Ем - Еговского месторождения. Согласно построенной модели, представления о геологическом строении залежи горизонта ВК, изменилось значимо. Внешняя проверка подтвердила более высокую точность, а значит, и более высокие прогностические свойства созданной геологической модели. Согласно уточнённому строению, уменьшилась площадь и нефтенасыщенные толщины залежи, и как следствие геологические запасы. Уточнение и детализация строения залежи горизонта ВК, позволит повысить эффективность доразведки слабо изученных частей и разработки. Предлагаемая в работе модель использована для создания гидродинамической модели и для обоснования наиболее эффективных геологотехнических мероприятий.

\section{Ключевые слова:}

Данные сейсморазведки, данные керна, данные геофизических исследований скважин, корреляция пластов, концептуальная модель, геологическая модель, викуловская свита, месторождение.

Эффективность решения любой геологической задачи в существенной степени определяется адекватностью модели соответствующего используемого объекта. В связи с этим построение трехмерных геологических моделей (3D ГM), учитывающих весь объем геолого-геофизической информации, неоднородной по качеству и масштабу и неравномерно распределенной по площади и разрезу, остается актуальной задачей [1]. Это означает, что при создании геологической модели (ГМ) в обязательном порядке должна использоваться не только вся геолого-геофизическая и геолого-промысловая информация, но и все доступные виды косвенной и априорной информации. Использование косвенной информации требует статистического анализа различных параметров, как правило, целевых в решаемой задаче от различных наборов замеров [2]. Привлечение априорной информации для расчётов при создании ГМ возможно после формализации геологических закономерностей. И тем не менее, несмотря на достаточно большие объёмы различных видов информации, используемой при 
построении ГМ, практически все геологические задачи являются некорректными, так как имеют бесчисленное множество решений $[3,4]$. В этих условиях задача моделирования заключается в создании модели, в которой согласованы все виды информации, на которой она базируется, и описании по возможности различных неоднородностей. Отметим, что, как правило, именно неоднородности представляют большой интерес при решении большинства геологических задач [5]. Ну, и наконец, для контроля прогностических свойств моделей необходимо проводить внешнюю проверку.

Как показывает практический опыт, одним из важных видов косвенной информации является концептуальная модель изучаемого объекта. В настоящее время в литературе под концептуальной моделью однозначно понимаются две компоненты: седиментационная и тектоническая составляющие. В представленной работе изучается объект, на котором по материалам сейсмики уже создана тектоническая составляющая, поэтому в работе строится седиментационная компонента.

Объектом исследований в данной работе является важный продуктивный горизонт - викуловская свита Ем-Еговского ЛУ. Викуловская свита выделена в 1954 г. Н.Н. Ростовцевым по скважине в пос. Викулово Тюменской области $[6,7]$. Изучение нефтегазового потенциала свиты начато по инициативе Ю.Н. Карагодина, и продуктивность впервые обоснована на керне из скважины Лорбинская № 35 около 50 лет назад [8]. Затем нефтеносность свиты подтвердилась данными по скважинам № 31 и 38 .

Отложения викуловской свиты Красноленинского свода, обладая высокой продуктивностью, характеризуются сложным геологическим строением. При этом большое число залежей разбурены редкой сеткой скважин, причем зачастую крайне неравномерной, следствием чего является значимый недостаток эмпирической информации для построения адекватной трехмерной геологической модели.

С целью изучения генезиса отложений викуловской свиты проанализирован керновый материал по восьми скважинам, расположенным в различных участках Ем-Еговского месторождения (№ № 1891, 1895, 1917, 2548, 3665, 3682, 6647 и 30034P). Выполнена классификация характерных форм каротажных диаграмм ГИС для продуктивных пластов $[9,10]$.

Схема мелководно-морских обстановок заимствована из работ Л.Н. Ботвинкиной, M.R. Lider, H.G. Reading, H.-E. Reineck и I.B. Singh, R.C. Selley [11-15]. В соответствие с этой схемой выделяются фации дальней, переходной и предфронтальной зон пляжа и собственно пляж (нижний и верхний).

C помощью электрометрической методики В.С. Муромцева, используя результаты исследований кернового материала и данные ГИС, в пределах месторождения выделены следующие группы фаций в пласте $\mathrm{BK}_{1}$ викуловской свиты: дальняя зона пляжа, переходная зона пляжа и предфронтальная зона. Линия предфронтальной зоны пляжа проведена условно и не использовалась при трехмерном геологическом моделировании в виду малого объема исходной информации. Анализ форм диаграммы ПС, ГК и ИК позволил определить типовые модели перечисленных ГИС и провести классификацию фаций по характерным формам каротажных диаграмм.

Отложения дальней зоны пляжа формируются ниже уровня штормовых волн. Данные отложения представлены градационно-слоистым переслаиванием пород от аргиллитов до алевролитов и тонкозернистых песчаников (рис. 1).

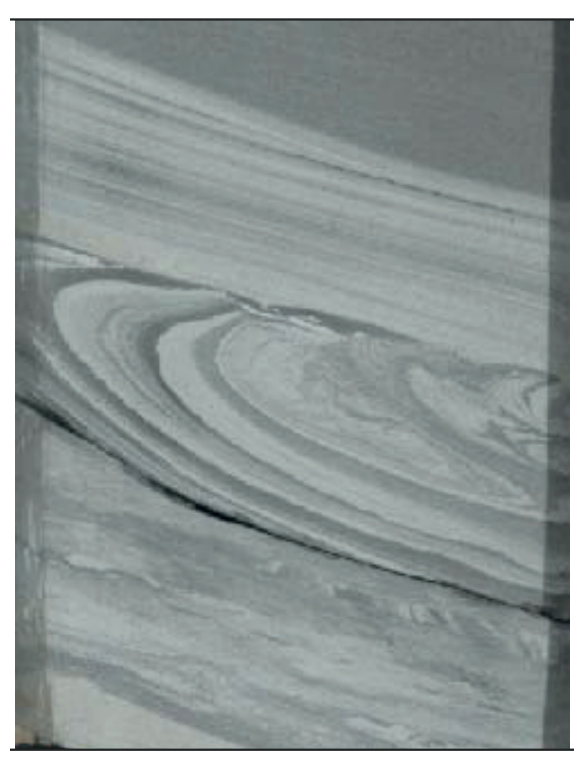

Рис.1. Переслаивание градационное аргиллита и песчаника тонкозернистого алевритового. Ем-Еговская площады, скв. 3682, горизонт ВК, инт. 1471,10-1471,25 м

Fig. 1. Intercalation gradation of mudstone and sandstone fine-grained aleurite. Em-Egovskaya area, well 3682, horizon $V K_{1}$, int. 1471,10-1471,25 m

Электрометрическая модель фации дальней зоны пляжа в формализованном виде представляет собой аномалию ПС в форме треугольника, расположенную в зоне отрицательных отклонений диаграммы. Кровельная линия ПС наклонная, чаще всего зубчатая или рассеченная, но может быть и прямой. Подошвенная линия также наклонная зубчатая, рассеченная или прямая. Значение $\alpha_{\text {пс }}$ достигает 0,8-0,6 д. ед. Кровельная линия ИК наклонная волнистая, боковая и подошвенная - наклонные, волнистые. Кровельная линия ГК зубчатая наклонная, боковая - зубчатая или рассеченная, подошвенная линия также наклонная зубчатая или рассеченная. Типовая электрометрическая модель этой субфации представлена на рис. 2. Желтым цветом выделен коллектор.

Переходная зона представлена чередованием глинисто-алевролитовых и песчаных прослоев в отложениях и характеризуется чередованием 

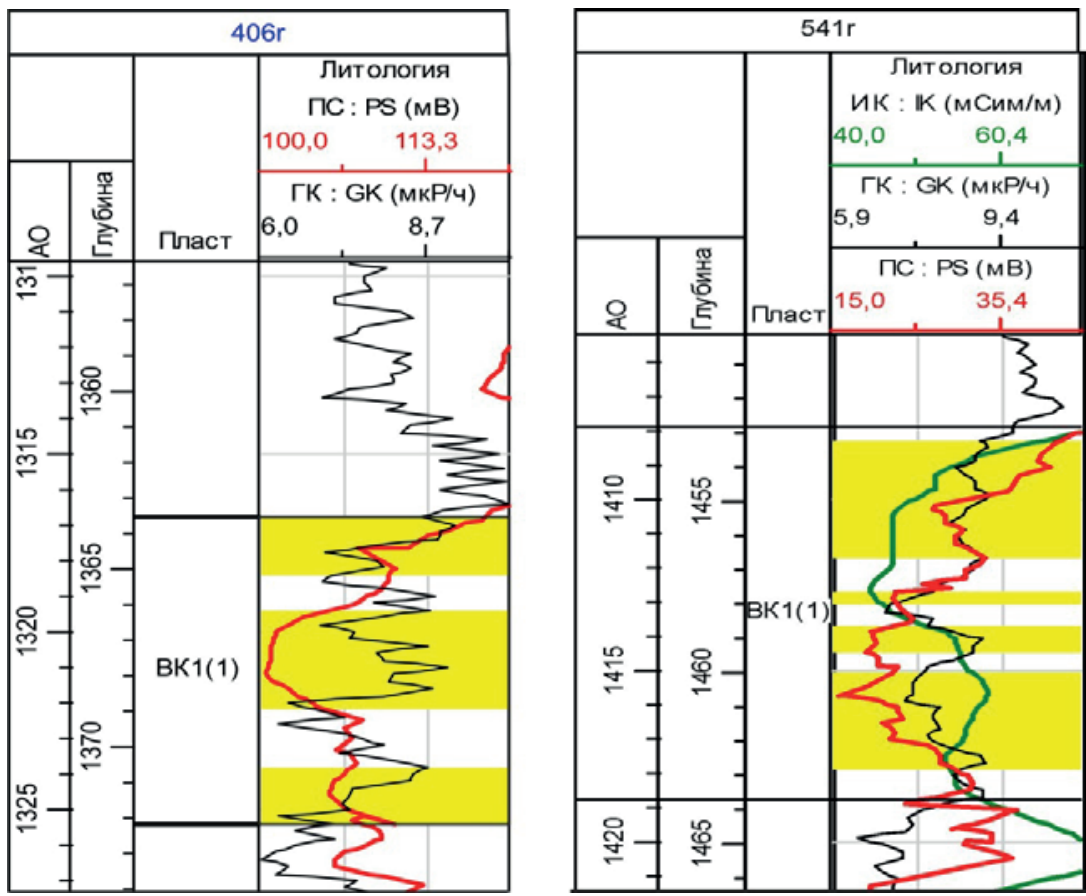

Рис. 2. Типовая электрометрическая модель отложений фации дальней зоны пляжа

Fig. 2. Typical electrometric model of the far-field facies deposits

условий высокой и низкой энергии волн, так как находится между средними базисами штормовых и спокойных волн. Текстуры продуцируются штормами (рис. 3).

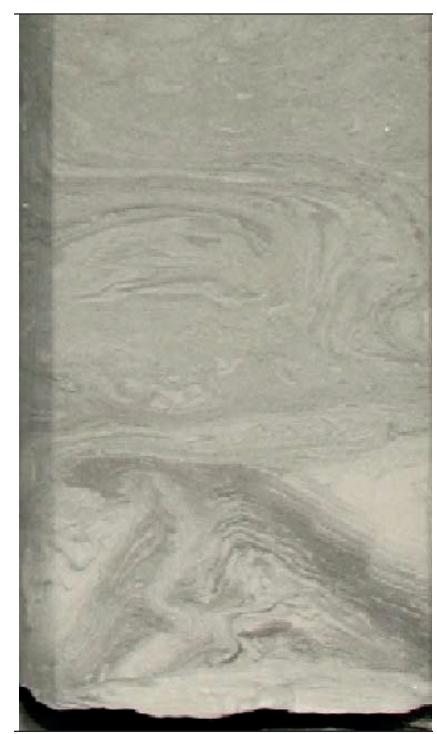

Рис. 3. Деформационная текстура, развитая во время отложения алевритопесчаного осадка. Ем-Еговская площадь, скв. 30034P, горизонт ВК ${ }_{1}$, инт. 1496,65-1496,80 м

Fig. 3. Texture of cosedimentation deformation, developed during deposition of aleurite sand sediment (convoluted stratification, possibly slipping).Em-Egovskaya area, well 30034P, horizon $V K_{1}$, int. 1496,65-1496,80 m

Электрометрическая модель фации переходной зоны представляет собой неравнобедренную трапе- цию, расположенную в зоне отрицательных отклонений диаграммы ПС ( $\alpha_{\text {Пс }} 0,4$ д. ед.). Кровельные линии моделей ГК и ИК наклонные прямые, боковые - зубчатые, подошвенные - наклонные волнистые. Ширина аномалии достигает единиц, иногда десятков метров. Типовая электрометрическая и модели ГК и ИК этой субфации представлены на рис. 4.

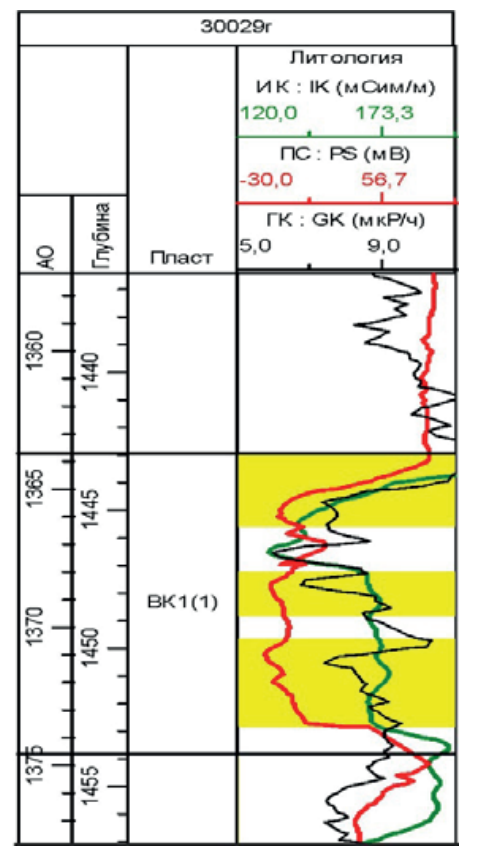

Pис. 4. Типовая электрометрическая модель отложений фаиии переходной зоны пляжа

Fig. 4. Typical electrometric model of transition beach area sediment 
Геологические и фильтрационно-ёмкостные характеристики викуловской свиты в пределах ЕмЕговского месторождения приведены в табл. 1, где через $\mathrm{H}_{\text {эф }}$ обозначена эффективная толщина, $\mathrm{K}_{\text {пес }}-$ коэффициент песчанистости, $\mathrm{K}_{\text {п }}$ - коэффициент открытой пористости, $\mathrm{K}_{\text {пр }}-$ коэффициент проницаемости, $\mathrm{K}_{\text {нн }}$ - коэффициент начальной нефтенасыщенности. Из анализа данных таблицы видно, что породы пласта наиболее значимо изменчивы по $\mathrm{K}_{\text {пр }}$ и $\mathrm{K}_{\text {п }}$.

Таблица 1. Геологические характеристики викуловской свиты Ем-Еговского месторождения

Table 1. Geological characteristic of vikulovskaya suits of EmEgouskoe field

\begin{tabular}{|c|c|c|c|c|c|c|}
\hline \multirow{2}{*}{$\begin{array}{c}\text { Статистическая } \\
\text { характеристика } \\
\text { Statistical characteristic }\end{array}$} & $\begin{array}{l}\mathrm{H}_{\ni \phi} \\
\mathrm{H}_{\mathrm{ef}}\end{array}$ & $\begin{array}{l}\mathrm{H}_{\text {эф.нн }} \\
\mathrm{H}_{\text {ef.os }}\end{array}$ & $\begin{array}{l}\mathrm{K}_{\text {Iec }} \\
\mathrm{K}_{\text {sand }}\end{array}$ & $\begin{array}{c}\mathrm{K}_{\text {II }} \\
\mathrm{K}_{\text {por }}\end{array}$ & $\begin{array}{l}\mathrm{K}_{\mathrm{HH}} \\
\mathrm{S}_{\mathrm{oil}}\end{array}$ & \multirow{2}{*}{\begin{tabular}{|c|}
$\mathrm{K}_{\mathrm{Ip}}$ \\
$\mathrm{n} * 10^{-3} \mathrm{MKM}^{2}$ \\
$\mathrm{~K}_{\text {perm }}$ \\
$\mathrm{n} * 10^{-3} \mu \mathrm{m}^{2}$ \\
\end{tabular}} \\
\hline & \multicolumn{2}{|c|}{$\mathrm{M} / \mathrm{m}$} & \multicolumn{3}{|c|}{ д. ед./u.s. } & \\
\hline Наименьшее/Least & 4,7 & 0,58 & 0,29 & 0,247 & 0,205 & 6,93 \\
\hline Наибольшее/Most & 36,3 & 33,3 & 0,83 & 0,301 & 0,613 & 56,109 \\
\hline Среднее значение/Mean & 14,1 & 13,3 & 0,52 & 0,280 & 0,482 & 26,1 \\
\hline Дисперси & 2,64 & 23,3 & 0,006 & 0,005 & 0,003 & 68,4 \\
\hline $\begin{array}{l}\text { Стандартное отклонение } \\
\text { Standard deviaton }\end{array}$ & 1,62 & 4,82 & 0,08 & 0,07 & 0,05 & 8,27 \\
\hline $\begin{array}{l}\text { Коэффициент вариации } \\
\text { Variation coefficient, \% }\end{array}$ & 15,9 & 2,76 & 14,9 & 25,3 & 12,7 & 29,3 \\
\hline $\begin{array}{l}\text { Объём выборки } \\
\text { Sample size }\end{array}$ & 1250 & 1250 & 1250 & 1250 & 1250 & 1250 \\
\hline
\end{tabular}

На карту седиментационных обстановок нанесены начальные дебиты (добыча за первый месяц эксплуатации скважины) по скважинам, а статистические характеристики этих дебитов приведены в табл. 2. Из анализа карты видно, что переходная зона пляжа в целом характеризуется большими дебитами относительно дальней зоны (рис. 5, табл. 2) и, как показывает коэффициент вариации, заметно более выдержанными.

Таблица 2. Статистические характеристики начальных деби тов скважин по фациальным зонам. Горизонт $B K_{1}$ Ем-Еговского месторождения

Table 2. Statistical characteristic of initial debit of sedimental areas. Horizon $\mathrm{VK}_{1}$ of Em-Egovskoe field

\begin{tabular}{|l|c|c|}
\hline \multirow{1}{*}{$\begin{array}{c}\text { Статистическая } \\
\text { характеристика }\end{array}$} & \multicolumn{2}{|c|}{$\begin{array}{c}\text { Начальный дебит нефти, т/сут } \\
\text { Initial oil production rate, t/day }\end{array}$} \\
\cline { 2 - 3 } & $\begin{array}{c}\text { Дальняя зона } \\
\text { пляжа } \\
\text { Far beach area }\end{array}$ & $\begin{array}{c}\text { Переходная зона } \\
\text { пляжа } \\
\text { Transition beach area }\end{array}$ \\
\hline Наименьшее/Least & 7,0 & 20,0 \\
\hline Наибольшее/Most & 827,0 & 1347,0 \\
\hline Среднее значение/Mean & 300,7 & 886,0 \\
\hline $\begin{array}{l}\text { Дисперсия/стандартное } \\
\text { отклонение } \\
\text { Dispersion/Standard deviation }\end{array}$ & $42329,7 / 205,7$ & $170339,2 / 412,7$ \\
\hline $\begin{array}{l}\text { Коэффициент вариации } \\
\text { Variation соеfficient }\end{array}$ & 68,5 & 46,5 \\
\hline 0бъём выборки/Sample size & 405 & 179 \\
\hline
\end{tabular}

Сравнение геологических и фильтрационно-ёмкостных характеристик обоснованных фаций дают данные табл. 3 , которые показывают, что переход- ная зона пляжа характеризуется заметно большими значениями $\mathrm{H}_{\text {э.нн }}$ и $\mathrm{K}_{\text {пр }}$, причем изменчивость эффективных нефтенасыщенных толщин заметно меньше.

Для дальнейшего изучения геологического строения отложений Викуловской свиты Ем-Еговского месторождения построена трехмерная геологическая модель её продуктивных отложений с помощью программного комплекса «Irap RMS 2013.1.2» компании «Roxar» («Emerson group of companies») согласно РД 153-39.0-047-00 [16, 17].

Начальным этапом создания 3D ГM является построение структурного каркаса. Основные части структурного каркаса модели - стратиграфические поверхности пластов и границы пластов в скважинах.

Размер участка для моделирования выбран в соответствии с предполагаемыми контурами нефтеносности, а также расположением краевых скважин [18]. Область геологического моделирования охватывает Ем-Еговский ЛУ с расширением границ на 2 км. Размер участка моделирования составляет около $49 \times 45$ км, общая толщина отложений достигает порядка 95 м.

При трехмерном моделировании использованы данные по 1322 скважинам, в том числе: по 116 разведочным и по 1206 эксплуатационным. В период с 2008-2014 гг. пробурено ещё 5 разведочных, 15 горизонтальных, 25 боковых стволов и 147 эксплуатационных скважин. Данные по новым скважинам также использованы при построении 3D ГМ.

Для построения структурного каркаса в качестве тренда используется структурная (стратиграфическая) поверхность отражающего горизонта «M1», полученная по данным 3D сейсморазведки и не использованная в предыдущих моделях. Этот ОГ хорошо выдержан по всей площади и отождествляется кровлей горизонта $\mathrm{BK}_{1}$ (рис. 6).

Для более корректного моделирования условий осадконакопления в продуктивной толще викуловских отложений выделены и прослежены горизонты $\mathrm{BK}_{3}, \mathrm{BK}_{2}$ и $\mathrm{BK}_{1}$, объединенные в один подсчетный объект $\mathrm{BK}_{1-3}$.

Горизонт $\mathrm{BK}_{1}$ приурочен к кровельной части викуловской свиты. Кровля пласта однозначно выделяется в разрезе по комплексу методов ПС, ИК, ГК, БК. Расчлененность пласта равномерная, пропластки глин и песчаников следятся довольно уверенно на протяженных участках площади.

Строение горизонтов $\mathrm{BK}_{2}, \mathrm{BK}_{3}$ - это ритмичное переслаивание мелкозернистых песчаников и алевролитов, чередующееся с прослоями и линзами глинистых алевролитов и глин. Внутри горизонта $\mathrm{BK}_{1}$ выделено три седиментационных цикла, для которых характерна довольно хорошая выдержанность по площади. В кровле третьего цикла практически во всех скважинах уверенно выделяется уплотненный известковый пропласток. Выделенные горизонты являются устойчивыми единицами разреза, хорошо выделяются на диаграммах ПС, 


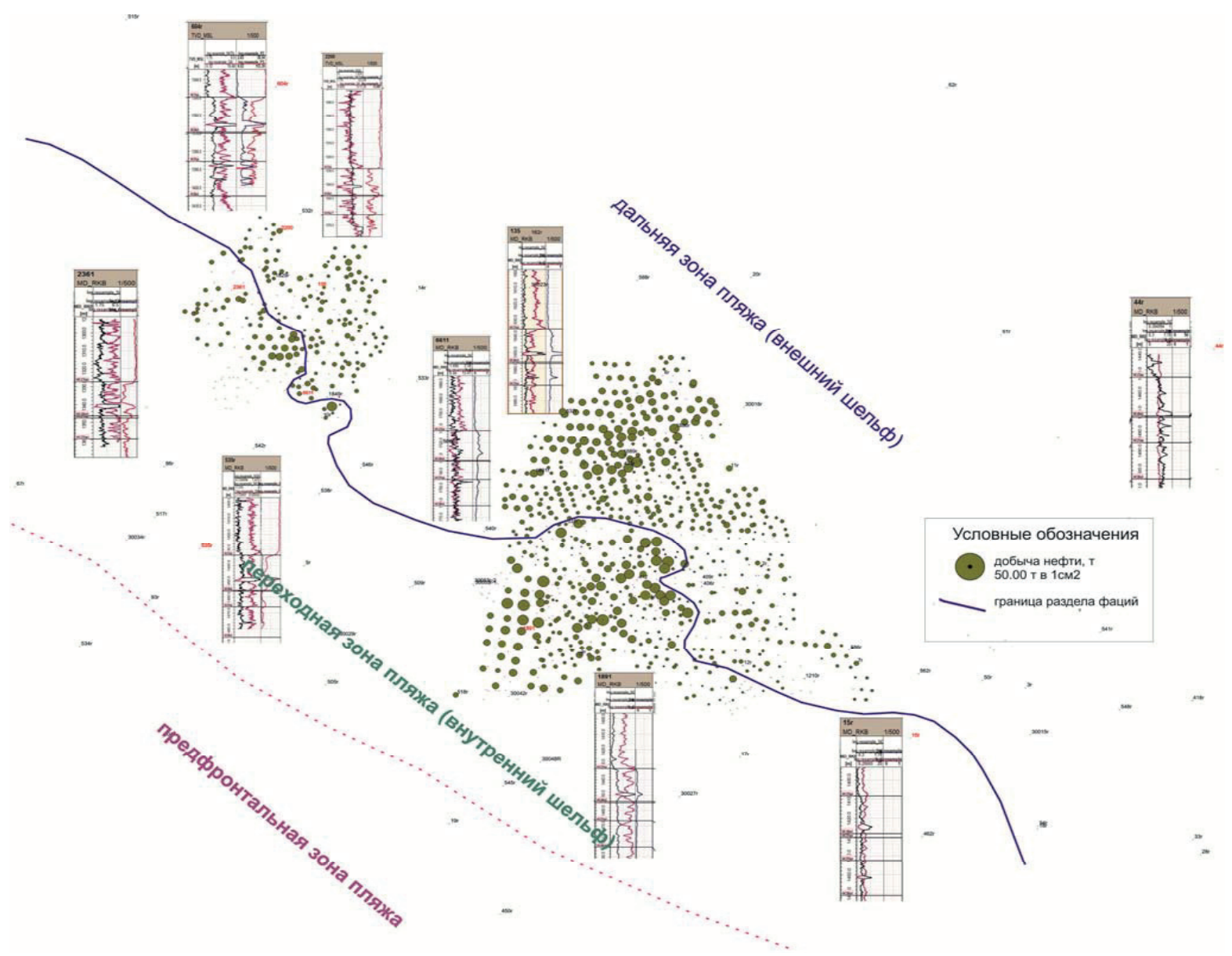

Pис. 5. Седиментационные обстановки накопления осадков пласта ВК викуловской свиты Ем-Еговского месторождения

Fig. 5. Sedimentation conditions of sediment accumulation of $V K_{1}$ vikulovskaya suit of Em-egovskoe field

Таблица 3. Геологические характеристики горизонта ВК викуловской свиты Ем-Еговского месторождения по зонам седиментации (1 - дальняя зона пляжа, 2 - переходная зона пляжа)

Table 3. Geological characteristics of the horizon VK $\mathrm{K}_{1}$ of vikulovskaya suite in Em-Egovskoe field on sedimentation areas (1 - the beach area, 2 - the transition beach area)

\begin{tabular}{|c|c|c|c|c|c|c|c|c|c|c|c|c|}
\hline \multirow{2}{*}{$\begin{array}{l}\text { Статистическая характеристика } \\
\text { Statistical characteristic }\end{array}$} & \multicolumn{2}{|c|}{$\begin{array}{l}\mathrm{H}_{3 \phi}, \mathrm{M} \\
\mathrm{H}_{\mathrm{ef}}, \mathrm{m}\end{array}$} & \multicolumn{2}{|c|}{$\begin{array}{l}\mathrm{H}_{\text {эक.HH }}, \mathrm{M} \\
\mathrm{H}_{\text {ef.os }}, \mathrm{m}\end{array}$} & \multicolumn{2}{|c|}{$\begin{array}{l}\mathrm{K}_{\text {пес }}, \text { д. ед. } \\
\mathrm{K}_{\text {sand }} \text {, u.s. }\end{array}$} & \multicolumn{2}{|c|}{$\begin{array}{l}\mathrm{K}_{\text {п }} \text {, д. ед. } \\
\mathrm{K}_{\text {por, }} \text {,u.s. }\end{array}$} & \multicolumn{2}{|c|}{$\begin{array}{l}\mathrm{K}_{\text {пp }}, \mathrm{n} * 10^{-3} \mathrm{MKM}^{2} \\
\mathrm{~K}_{\text {perm }}, \mathrm{n} * 10^{-3} \mu \mathrm{m}^{2}\end{array}$} & \multicolumn{2}{|c|}{$\begin{array}{c}\mathrm{K}_{\text {нн, }} \text {, д. ед. } \\
\mathrm{S}_{\text {oil }} \text {, u.s. }\end{array}$} \\
\hline & 1 & 2 & 1 & 2 & 1 & 2 & 1 & 2 & 1 & 2 & 1 & 2 \\
\hline Наименьшее/Least & 4,7 & 5,8 & 0,58 & 0,59 & 0,32 & 0,29 & 0,250 & 0,247 & 10,620 & 6,930 & 0,205 & 0,326 \\
\hline Наибольшее/Most & 22,1 & 36,3 & 33,3 & 24,95 & 0,83 & 0,90 & 0,297 & 0,301 & 43,864 & 56,109 & 0,613 & 0,588 \\
\hline Среднее значение/Mean & 14,2 & 15.2 & 13,3 & 13,2 & 0,52 & 0,51 & 0,280 & 0,281 & 25,837 & 26,952 & 0,475 & 0,497 \\
\hline $\begin{array}{l}\text { Дисперсия/стандартное отклонение } \\
\text { Dispersion/Standard deviation }\end{array}$ & $\begin{array}{l}8,4 / \\
2,7\end{array}$ & $\begin{array}{c}11,5 / \\
3,4\end{array}$ & $\begin{array}{c}27,2 / \\
5,2\end{array}$ & $\begin{array}{c}16,9 / \\
4,1\end{array}$ & $\begin{array}{l}0,004 / \\
0,067\end{array}$ & $\begin{array}{l}0,006 / \\
0,077\end{array}$ & $\begin{array}{c}0,0004 / \\
0,006\end{array}$ & $\begin{array}{c}0,0005 / \\
0,008\end{array}$ & $\begin{array}{c}1,578 / \\
6,448\end{array}$ & $\begin{array}{c}50,099 / \\
7.078\end{array}$ & $\begin{array}{l}0,003 / \\
0,050\end{array}$ & $\begin{array}{l}0,002 / \\
0,049\end{array}$ \\
\hline \begin{tabular}{|l|} 
Коэффициент вариации, \% \\
Variation coefficient, \%
\end{tabular} & 19 & 22 & 39,2 & 31,1 & 13 & 15 & 21 & 28 & 25 & 26,2 & 10,5 & 9,9 \\
\hline Объём выборки/Sample size & 794 & 456 & 794 & 456 & 794 & 456 & 794 & 456 & 794 & 456 & 794 & 456 \\
\hline
\end{tabular}

ГК, ИК, БК; довольно легко поддаются типизации, уверенно прослеживаются и сопоставляются по площади. На рис. 7 приведена схема детальной корреляции продуктивных горизонтов викуловской толщи на площади Ем-Еговского ЛУ.

Геологические характеристики выделенных седиментационных циклов приведены в табл. 4. Из приведенных данных следует, что геообъект $\mathrm{BK}_{2}$, как показывают коэффициенты вариации, обладает наибольшей латеральной неоднородностью по параметрам $\mathrm{K}_{\text {пр }}, \mathrm{H}_{\text {эф }}, \mathrm{H}_{\text {эф.ни }}$ и $\mathrm{K}_{\text {пес }}$, а геообъект $\mathrm{BK}_{1}-$ наибольшими значениями эффективных и эффективных нефтенасыщенных толщин и коэффициента нефтенасыщенности. 


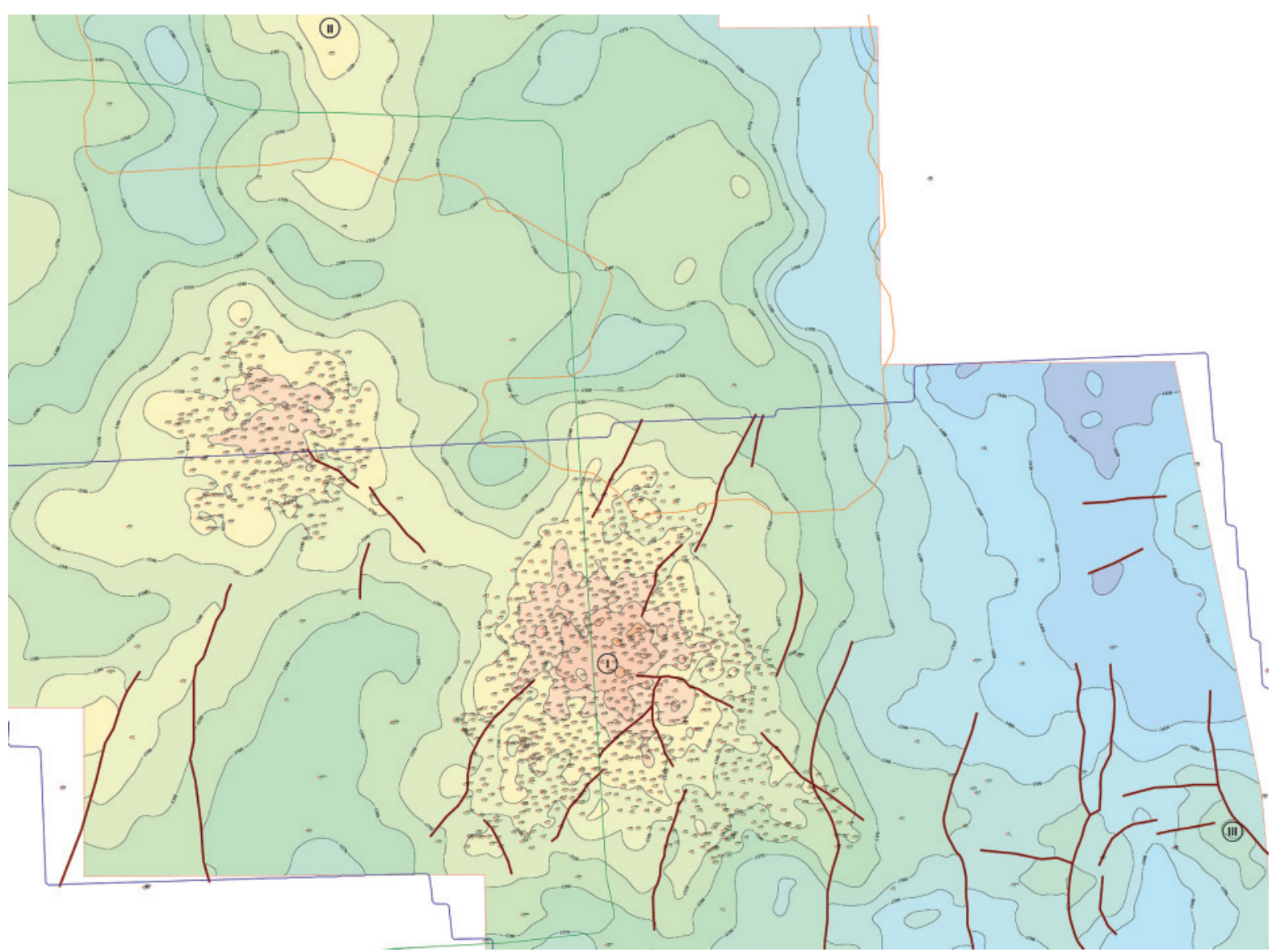

Puc. 6. Структурная карта по кровле отражающего горизонта «М1» (кровля горизонта ВК $\left.{ }_{1}\right)$

Fig. 6. Structural top map of the reflecting horizon «M1» $\left(V K_{1}\right.$ horizon top)

Таблица 4. Геологические характеристики викуловской свиты Ем-Еговского месторождения по седиментационныл циклам ВК ${ }_{1}$, ВК ${ }_{2}$, ВК $\kappa_{3}$ Table 4. Geological characteristics of the vikulovskaya formation of the Em-Egovskoye deposit according to sedimentation cycles VK $\mathrm{K}_{1}$, VK $\mathrm{VK}_{3}$

\begin{tabular}{|c|c|c|c|c|c|c|c|c|c|c|c|c|c|c|c|}
\hline \multirow{2}{*}{$\begin{array}{c}\text { Статистическая } \\
\text { характеристика } \\
\text { Statistical characteristic }\end{array}$} & \multicolumn{3}{|c|}{$\begin{array}{l}\mathrm{H}_{э \Phi}, \mathrm{M} \\
\mathrm{H}_{\mathrm{ef}}, \mathrm{m}\end{array}$} & \multicolumn{3}{|c|}{$\begin{array}{l}\mathrm{K}_{\text {песе }} \text {, д. ед. } \\
\mathrm{K}_{\text {sand }} \text {, u.s. }\end{array}$} & \multicolumn{3}{|c|}{$\begin{array}{l}\mathrm{K}_{\mathrm{I}}, \text { д. ед. } \\
\mathrm{K}_{\text {por }} \text {, u.s. }\end{array}$} & \multicolumn{3}{|c|}{$\begin{array}{l}\mathrm{K}_{\text {IIp }}, \mathrm{n} * 10^{-3} \mathrm{MKM}^{2} \\
\mathrm{~K}_{\text {perm }}, \mathrm{n} * 10^{-3} \mu \mathrm{m}^{2}\end{array}$} & \multicolumn{3}{|c|}{$\begin{array}{l}\mathrm{K}_{\mathrm{Hн}} \text {, д. ед. } \\
\mathrm{S}_{\mathrm{oil}} \text {, u.s. }\end{array}$} \\
\hline & $\overline{\mathrm{BK}_{1}}$ & $\mathrm{BK}_{2}$ & $\mathrm{BK}_{3}$ & $\mathrm{BK}_{1}$ & $\mathrm{BK}_{2}$ & $\mathrm{BK}_{3}$ & $\mathrm{BK}_{1}$ & $\mathrm{BK}_{2}$ & $\mathrm{BK}_{3}$ & $\mathrm{BK}_{1}$ & $\mathrm{BK}_{2}$ & $\mathrm{BK}_{3}$ & $\mathrm{BK}_{1}$ & $\mathrm{BK}_{2}$ & $\mathrm{BK}_{3}$ \\
\hline Наименьшее/Min & 4,7 & 2,0 & 2,1 & 0,29 & 0,14 & 0,25 & 0,235 & 0,235 & 0,236 & 6,93 & 4,4 & 6,4 & 0,205 & 0,054 & 0,015 \\
\hline Наибольшее/Max & 36,6 & 13,3 & 13,0 & 0,9 & 0,93 & 0,71 & 0,301 & 0,301 & 0,305 & 56,11 & 69,4 & 69,4 & 0,747 & 0,781 & 0,762 \\
\hline Среднее значение/Mean & 14,2 & 6,1 & 9,3 & 0,52 & 0,49 & 0,54 & 0,280 & 0,277 & 0,278 & 25,84 & 24,24 & 25,5 & 0,61 & 0,411 & 0,331 \\
\hline $\begin{array}{l}\text { Дисперсия/стандартное от- } \\
\text { клонение Dispersion/Stan- } \\
\text { dart deviation }\end{array}$ & $\begin{array}{l}2.6 / \\
1,62\end{array}$ & $\begin{array}{c}1,7 / \\
1,3\end{array}$ & $\begin{array}{r}2,7 / \\
1,6\end{array}$ & $\begin{array}{c}0,006 / \\
0,077\end{array}$ & $\begin{array}{c}0,009 / \\
0,095\end{array}$ & $\begin{array}{r}0,007 / \\
0,082\end{array}$ & $\begin{array}{c}0,00005 / \\
0,008\end{array}$ & $\begin{array}{c}0,000006 / \\
0,008\end{array}$ & $\begin{array}{c}0,00007 / \\
0,082\end{array}$ & $\begin{array}{c}68,3 / \\
8,3\end{array}$ & $\begin{array}{c}70,6 / \\
8,4\end{array}$ & $\begin{array}{c}63,8 / \\
7,99\end{array}$ & $\begin{array}{c}0,002 / \\
0,05\end{array}$ & $\begin{array}{c}0,01 / \\
0,11\end{array}$ & $\begin{array}{c}0,01 / \\
0,1\end{array}$ \\
\hline $\begin{array}{l}\text { Коэффициент вариации, \% } \\
\text { Variation coefficient }\end{array}$ & 11,4 & 21,3 & 17,2 & 14,9 & 19,4 & 15,2 & 2,7 & 2,9 & 29,5 & 29,3 & 34,7 & 31,3 & 7.5 & 26,7 & 30,2 \\
\hline Объём выборки/Sample size & 1250 & 1027 & 223 & 1250 & 1250 & 223 & 1250 & 1250 & 223 & 1250 & 1250 & 223 & 1250 & 1250 & 214 \\
\hline
\end{tabular}

Структурные карты по кровлям горизонтов строились методом схождения от кровли пласта $\mathrm{BK}_{1}$. Структурная модель включает пять структурных поверхностей (4 зоны) и 21 поверхность тектонических нарушений. Каждый горизонт моделировался как самостоятельная зона для достижения детальности модели и отражения стратифицированности викуловских отложений.

Проведен контроль качества построенных структурных поверхностей относительно страти- графических отметок горизонтов - невязки значений абсолютных отметок стратиграфических границ в точках скважин не превышают $\pm 0,2$ м. Это говорит об адекватности структурного каркаса.

Интерпретация сейсмического материала и данные бурения позволили уточнить геологическое строение данного участка (структурный план, модель тектонических нарушений). За счет использования новых данных уточнилась площадь залежи - на западе залежи наблюдается незначи- 


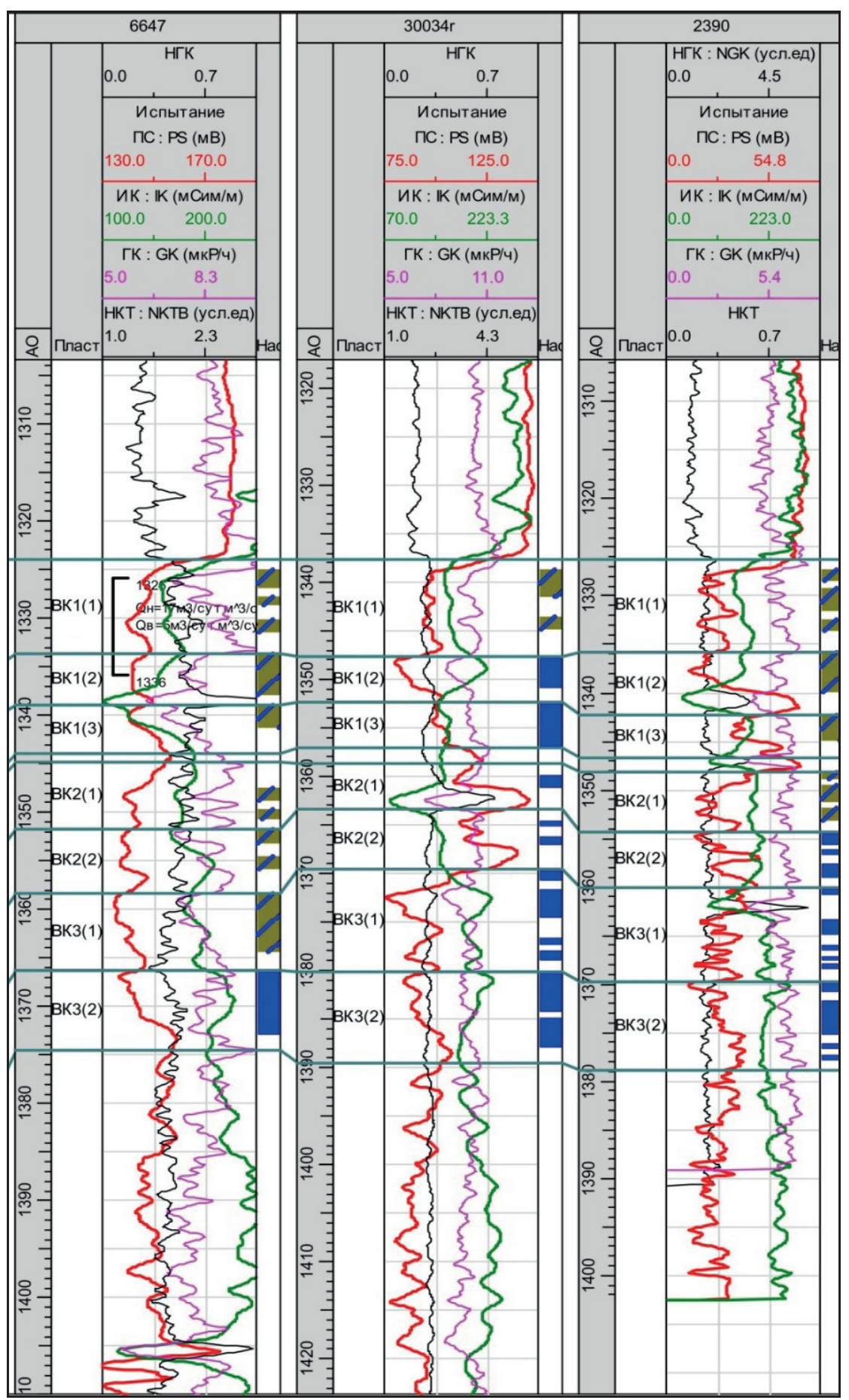

Pис. 7. Схема детальной корреляиии продуктивных горизонтов $B K_{3}, B K_{2}$ и ВК

Fig. 7. Scheme of detailed correlation of productive horizons $V K_{3}, V K_{2}$ and $V K_{1}$ vikulouskaya suite, Em-Egovskoe deposit

тельный прирост, в то время как на севере, северовостоке и юго-востоке залежи происходит списание нефтенасыщенной части.

Трёхмерная сетка построена в стратиграфических границах структурного каркаса. Шаг сетки по горизонтали $-50 \times 50$ м - принят, исходя из среднего расстояния между скважинами (150-250 м) [19, 20]. Из расчета 3D грида исключе- ны 31 скважина, по причине нахождения стволов в одной ячейке, а также 74 скважины по причине отсутствия РИГИС. Для всех пластов применялась пропорциональная схема напластования, в связи с отсутствием, согласно построенной седиментационной модели, размывов и перерывов в осадконакоплении. Параметры трехмерной сетки приведены в табл. 5 . 
Таблииа 5. Геометрические характеристики трехмерной сетки модели викуловской свиты

Table 5. Geometric characteristics of the three-dimensional grid of the model of the Vikulovskaya suite

\begin{tabular}{|c|c|c|c|c|c|}
\hline \multirow{2}{*}{ 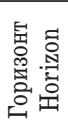 } & \multirow{2}{*}{$\begin{array}{c}\text { Количе- } \\
\text { ство слоев } \\
\text { Number of } \\
\text { layers }\end{array}$} & \multicolumn{3}{|c|}{$\begin{array}{l}\text { Толщина слоя, м } \\
\text { Thickness layers, m }\end{array}$} & \multirow{2}{*}{$\begin{array}{c}\text { Количество } \\
\text { ячеек } \\
\text { Number } \\
\text { of cells }\end{array}$} \\
\hline & & $\begin{array}{c}\text { наименьшая } \\
\text { least }\end{array}$ & $\begin{array}{c}\text { наибольшая } \\
\text { most }\end{array}$ & $\begin{array}{c}\text { средняя } \\
\text { mean }\end{array}$ & \\
\hline $\mathrm{BK}_{1}$ & 67 & 0,23 & 0,39 & 0,30 & 46627176 \\
\hline $\mathrm{BK}_{2}$ & 46 & 0,20 & 0,49 & 0,30 & 32012688 \\
\hline $\mathrm{BK}_{3}$ & 61 & 0,12 & 0,46 & 0,30 & 42451608 \\
\hline
\end{tabular}

Построение 3D модели литологии реализовано поэтапно:

1) построение двумерных трендов - карт песчанистости $\left(\mathrm{k}_{\text {пес }}\right)$ - по скважинным данным раздельно по зонам седиментации (рис. 2) для горизонта $\mathrm{BK}_{1}$, и карт $\mathrm{k}_{\text {пес }}$, построенных отдельно для горизонтов $\mathrm{BK}_{2}$ и $\mathrm{BK}_{3}$.

Карта $\mathrm{k}_{\text {тес }}$ для горизонта $\mathrm{BK}_{1}$ строилась для каждой зоны седиментации внутри заданного полигона, затем «сшивалась» со сглаживанием в 30нах границ фаций (рис. 8). Из рис. 8 видно, что 2D модель песчанистости является гладкой функцией не только в зонах выделенных фаций, но и на их границе. Переходная зона пляжа характеризуется локальными изменениями песчанистости по скважинам в отличие от предфронтальной зоны пляжа.
2) построение одномерных трендов - ГСР параметра литологии - раздельно по зонам седиментации - дальняя зона пляжа и переходная зона пляжа горизонта $\mathrm{BK}_{1}$ и ГСР для горизонтов $\mathrm{BK}_{2}$ и $\mathrm{BK}_{3}$ отдельно (рис. 9).

Необходимость построения четырёх одномерных и четырёх двумерных трендов обусловлена концептульной геологической моделью.

Предфронтальная зона пляжа проведена условно и не использовалась при построении 3D ГM, так как проходит на границе ЛУ и недостаток информации данного участка не позволяет корректно построить выделенную зону.

3) построение комбинированной трендовой $3 \mathrm{D}$ модели литологии $\left(\mathrm{K}_{\text {пес }}^{\mathrm{pp}}\right)$ по построенным трендам ГСР и $\mathrm{k}_{\text {пес }}$. В результате получена трендовая 3D модель коэффициента песчанистости, в которой для пласта $\mathrm{BK}_{1}$ в каждой зоне седиментации использовался свой ГСР и карта $\mathrm{k}_{\text {пес }}$, а также свой ГСР и карта $\mathrm{k}_{\text {пес }}$ для горизонтов $\mathrm{BK}_{2}$ и $\mathrm{BK}_{3}$.

4) интерполяция значений коэффициента песчанистости в данных РИГИС с использованием трёхмерного тренда $\mathrm{K}_{\text {пес }}^{\mathrm{rp}}$.

5) дискретизация непрерывной 3D модели песчанистости по граничному значению - 0,5 д. ед., результатом чего явилась 3D модель литологии $\left(\mathrm{K}_{\text {lito }}\right)$.

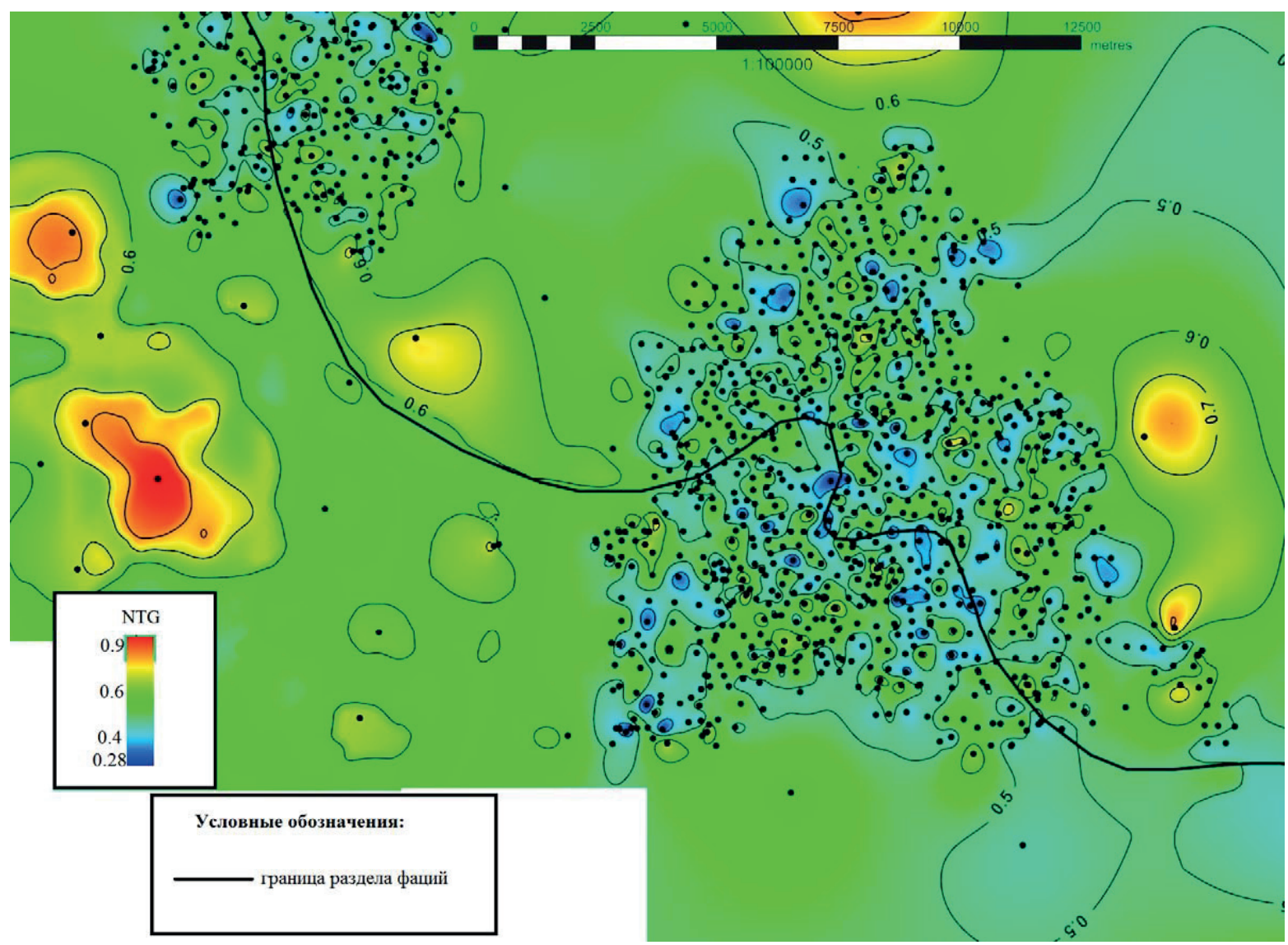

Pис. 8. Трендовая карта коэффициента песчанистости горизонта $B K_{1}$

Fig. 8. Trend map of the sand coefficient of horizon $V K_{1}$ 


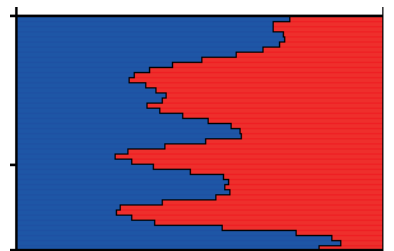

$a / a$

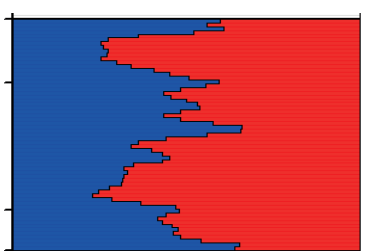

$\sigma / b$

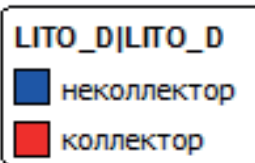

Рис. 9. ГСР параметра литологии по зонал седиментации: а) горизонт ВК, б) горизонт $\mathrm{BK}_{3}$

Fig. 9. GSR of lithology parameter by sedimentation zones: a) horizon $\mathrm{VK}_{2}, b$ ) horizon $\mathrm{VK}_{3}$

Корректность построенной литологической модели проверена использованием статистического анализа, сопоставлением двумерных карт эффективных толщин и песчанистости пластов, построенных на основе исходных данных и результирующих по модели 3D. На рис. 10 приведены средние параметры по геологической модели и по данным интерпретации ГИС. Графики ГСР и названные карты различаются незначимо, что свидетельствует об адекватном отражении неоднородности разреза и о внутренней сходимости всех разнородных и разноточных данных, использованных при построении трёхмерной геологической модели.
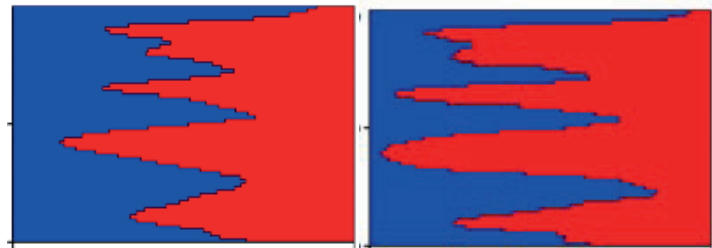

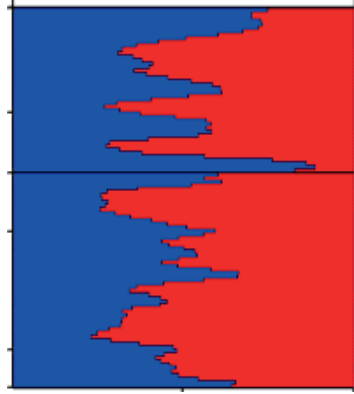

$a / a$

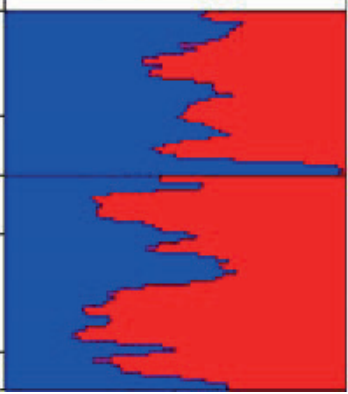

$\sigma / b$

\section{LITO_D|LITO_D

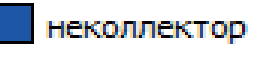 \\ коллектор}

Puc. 10. Сопоставление ГСР по 3D модели литологии и ВW. Вику ловскал свита (горизонты $B K_{1}, B K_{2}, B K_{3}$ ) а) осредненные скважинные данные, б) куб литологии

Fig. 10. Comparison of GSR for the $3 D$ model of lithology and BW.Vikulovskaya suite (horizons $V K_{1}, V K_{2}, V K_{3}$ ) a) $B W, b$ ) cube of lithology
Интерполяция коэффициента открытой пористости $\left(\kappa_{\text {пI }}\right)$ на трехмерную сетку осуществлена алгоритмом «Kriging» с использованием двумерных трендов - трех карт коэффициента открытой пористости по каждому пласту. Карты $\mathrm{K}_{\text {п }}$ для группы пластов ВК строились для каждой зоны седиментации внутри заданного полигона, затем «сшивались» со сглаживанием в зоне границ фаций. Для каждой зоны (дальняя зона пляжа и переходная зона пляжа) при построении $3 \mathrm{D}$ куба $\mathrm{K}_{\text {п }}$ задавались свои граничные значения пористости (минимальное и максимальное значение, табл. 5). На рис. 11 изображена карта коэффициента открытой пористости группы пластов ВК, полученная по результатам 3D моделирования. По данной карте можно сделать вывод о том, что переходная зона пляжа характеризуется более высокими значениями пористости по скважинам в отличие от предфронтальной зоны пляжа.

Интерполяция коэффициента нефтенасыщенности $\left(\kappa_{\text {нн }}\right)$ на трехмерную сетку осуществлена алгоритмом «Kriging» для ячеек-коллекторов выше поверхности ВНК. Интерполяция $\mathrm{K}_{\text {нн }}$ осуществлялось для всей модели сразу, т. к. объект $\mathrm{BK}_{1-3}$ имеет общий ВНК. Для дальней зоны пляжа и переходной зоны пляжа при построении $3 \mathrm{D}$ куба $\mathrm{K}_{\text {нн }}$ аналогично построению куба пористости задавались свои граничные значения начальной нефтенасыщенности (минимальное и максимальное значение, табл. 5).

Куб проницаемости $\mathrm{K}_{\text {пр }}$ получен по петрофизической зависимости от куба пористости: $\operatorname{LgK}_{\text {пр }}=0,1937 * \mathrm{~K}_{\text {пा }}-4,0677$.

Проведена внешняя проверка качества построенной модели. На рис. 12 приведен график зависимости начального дебита (добыча за первый месяц эксплуатации скважины) нефти $\left(\mathrm{q}_{\mathrm{H}}\right)$ от эффективной нефтенасыщенной $\left(\mathrm{h}_{\text {эф.нн }}\right)$ толщины. Из графика видно, что наблюдается тесная зависимость изменения $\mathrm{q}_{\text {н }}$ от $\mathrm{h}_{\text {эф.нн }}$, что говорит о неплохой внешней сходимости. Коэффициент детерминации составляет 0,75 .

Относительно начальных геологических запасов, числящихся на государственном балансе и утвержденных в 2004 г., списание нефти составило порядка $17 \%$. На изменение запасов повлияло, прежде всего, уменьшение площади залежи на $25 \%$. Площадь залежи уточнилась за счет использования новых данных 3D сейсмики. Также изменение запасов обусловлено уменьшением нефтенасыщенных толщин до $30 \%$.

Незначительные изменение таких подсчетных параметров, как пористость и нефтенасыщенность, объясняется возросшей изученностью месторождения. В 2008-2014 гг. пробурено 5 разведочных, 15 горизонтальных, 25 боковых ствола и 147 эксплуатационных скважин. В 2007-2008 гг. в юго-западной части ЛУ проведены 3D сейсморазведочные работы. Интерпретация сейсмического материала и данные бурения позволили уточнить геологическое строение данного участка (структурный план и модель тектонических нарушений). 


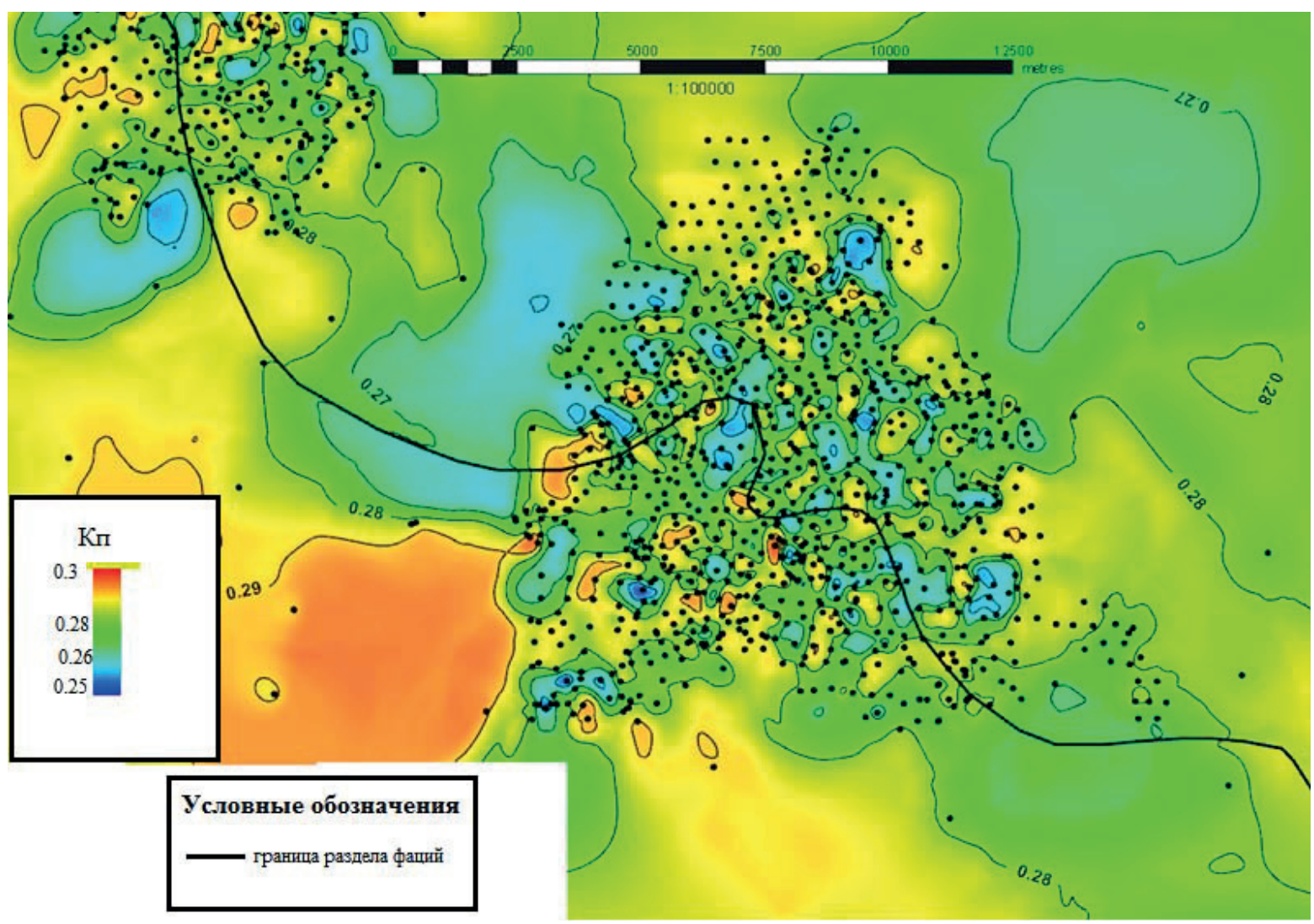

Pис. 11. Карта коэффициента пористости горизонта $B K_{1}$ по трехмерной геологической модели

Fig. 11. Map of the porosity coefficient of $V K_{1}$ horizon by the three-dimensional geological model

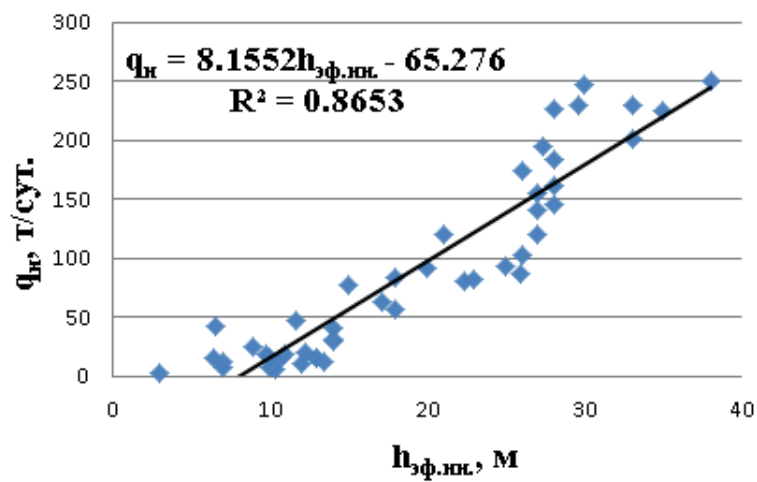

Pис. 12. Зависимость начального дебита нефти от эффективной нефтенасыщенной толщины. Викуловская свита ЕмЕговского месторождения

Fig. 12. Dependence of the initial oil production rate on the effective oil-saturated thickness. Vikulovskaya formation of the EmEgouskoe field

Геологические запасы нефти и газа подсчитаны объемным методом, используя следующие подсчетные параметры: эффективный объем ячеек, коэффициенты пористости и нефтенасыщенности, пересчетный коэффициент и плотность нефти.

На дальнюю зону пляжа приходится 66 \% общих запасов, на переходную - $34 \%$.

\section{Выводы}

1. По особенностям условий формирования отложений викуловской свиты горизонт $\mathrm{BK}_{1}$ в пределах Ем-Еговского месторождения можно разделить на три основные генетические зоны: дальняя зона пляжа, переходная зона пляжа и предфронтальная зона пляжа.

2. Горизонт $\mathrm{BK}_{1}$ приурочен к кровельной части викуловской свиты. Внутри горизонта $\mathrm{BK}_{1}$ выделено три седиментационных цикла, для которых характерна довольно хорошая выдержанность по площади.

3. Авторская концептуальная геологическая модель викуловской свиты на территории ЕмЕговского месторождения, а также расчленение горизонта $\mathrm{BK}_{1}$ на три пласта использовано при трехмерном геологическом моделировании.

4. При построении 3D модели литологии в качестве трендов в соответствии с построенной концептуальной моделью для горизонта $\mathrm{BK}_{1}$ использованы геолого-статистические разрезы (ГСР) по двум фациальным зонам моделируемой. Трендовые карты коэффициента песчанистости построены с учетом этих зон. Для каждого из горизонтов $\mathrm{BK}_{2}$ и $\mathrm{BK}_{3}$ построен свой ГСР и трендовые карты песчанистости. Анало- 
гично, при построении трехмерной модели пористости использованы трендовые карты пористости, построенные по фациям.

5. В связи с привлечением новых данных изменилась геометрия залежи. Согласно новым сейсмическим данным и дополнительным материалам по вновь пробуренным 192 скважинам, и заметного уточнения трехмерной геологической модели, площадь нефтеносности уменьшилась на $25 \%$ от ранее представляемой.

6. Проведена оценка качества построенной трехмерной геологической модели - внутренняя проверка на сходимость всего объёма разнородной и разноточной информации - сравнение гистограмм по данным скважин и данным 3D кубов.

7. Качество 3D модели подтверждается результатами внешней проверки, сопоставлением на-

\section{СПИСОК ЛИТЕРАТУРЫ}

1. Забоева А.А. Разработка методик трехмерного геомоделирования в условиях неоднородности и неравномерности геологогеофизической информации (на примере месторождений Западной Сибири): дис. ... канд. геол.-минерал. Наук. - Тюмень, 2012. $-167 \mathrm{c}$.

2. Deutsch C.V. Geostatistical reservoir modeling. - New York: 0xford University Press, 2002. - 376 p.

3. Основы геологического моделирования (Ч. 1) / В.А. Белкина, С.Р. Бембель, А.А. Забоева, Н.В. Санькова. - Тюмень: Тюменский Государственный Нефтегазовый Университет, 2015. $168 \mathrm{c.}$

4. Martin R., Boisvert J.B. Towards justifying unsupervised stationary decisions geostatistical modeling: Ensemble spatial and multivariate clustering with geomodeling specific clustering metrics // Computers \& Geosciences. - 2018. - V. 120 - P. 82-96.

5. Stochastic Modeling and Geostatistics. Principles, Methods, and Case Studies (AAPG Computer Applications in Geology, No. 3) / Ed. by J.M. Yarus, R.L. Chambers. - Tulsa, Oklahoma: AAPG, 1994. - $379 \mathrm{p}$

6. Ростовцев Н.Н. Стратиграфический словарь мезозойских и кайнозойских отложений Западно-сибирской низменности. Л.: Недра, 1978. - 183 с.

7. Геологическое строение и перспективы нефтегазоносности Западно-Сибирской низменности / под общей ред. Н.Н. Ростовцева. - М.: Госгеологтехиздат, 1958. - 391с.

8. Карагодин Ю.Н. Нефть и газ викуловской свиты // Наука в Сибири. Издание СО РАН. - 2008. - № 41. - С. 10-13.

9. Александров А.А., Белкина В.А., Казанская Д.А. Генетическая классификация темпеститов // Территория Нефтегаз. 2014. - № 6. - С. 40-43.

10. Александров А.А., Белкина В.А., Казанская Д.А. Особенности геологического строения темпенситов в отложениях викуловской свиты // Нефть и газ. - 2015. - № 5. - С. 10-15.

11. Обстановки осадконакопления и фации: В 2-х т. Т. 1 / Х.Г. Рединг, Дж.Д. Коллинсон, Ф.А. Аллен, Т. Эллиотт, Б.Ш. Шрей- чальных дебитов нефти с эффективными нефтенасыщенными толщинами, коэффициент детерминации зависимости равен 0,75 .

8. Геологические запасы нефти посчитаны в целом и отдельно по зонам седиментации: на дальнюю зону пляжа приходится 66 \% начальных геологических запасов, на переходную $34 \%$. Отметим, что по зонам седиментации и первоначальные дебиты различаются значимо.

9. Построена дискретно-непрерывная модель, обладающая более высокими прогностическими свойствами.

10. Построенная трёхмерная геологическая модель продуктивного горизонта ВК $_{1}$ викуловской свиты Ем-Еговского лицензионного участка использована при гидродинамическом моделировании.

бер, Г.Д. Джонсон, К.Т. Болдуин, Б.У. Селлвуд, Х.К. Дженкинс, Д.А.В. Стоу, М. Эдуардз, А.Х.Г. Митчелл / Пер. с англ. / под ред. Х. Г. Рединга. - М.: Мир, 1990. - 352 с.

12. Selly R.C. Applied Sedimentology ( $2^{\text {nd }}$ ed.). - San Diego: Elsevier, $2000 .-523 \mathrm{p}$.

13. Reading H.G., Collinson J.D. Clastic coasts // Sedimentary Environments: processes, facies and stratigraphy. $3^{\text {rd }}$ ed. / Ed. by H.G. Reading. - Oxford: Wiley Blackwell, 1996. - 704 p.

14. An automatic variogram modeling method with high reliability fitness and estimates / Zhanglin Li, Xianin Zhang, Keith C. Clarke, Gang Liu, Rui Zhu // Computers \& Geosciences. - 2018. V. 120 - - P. 48-59.

15. Палеография Западно-Сибирского осадочного бассейна в меловом периоде / А.Э. Конторович, С.В. Ершов, В.А. Казаненков, Ю.Н. Карогодин, В.А. Конторович, Н.К. Лебедева, Б.Л. Никитенко, Н.И. Попова, Б.Н. Шурыгин // Геология и геофизика. 2014. - T. 55. - № 5-6. - C. 745-776.

16. Закревский К.Е. Практикум по геологическому 3D-моделированию. Построение тестовой модели в Petrel 2011. - М., 2012. $-114 \mathrm{c}$.

17. Струкова 0.В., Закревский К.Е. Геологическое моделирование в RMS. Практические упражнения. 2D и 3D моделирование. M.: ROXAR, 2012. $-694 \mathrm{c}$.

18. Практические советы по 3D геологическому моделированию / Б.В. Белозёров, А.В. Буторин, П.Н. Герасименко, Е.В. Журавлёва, Р.З. Фаизов. - СПб.: Газпромнефть НТЦ, 2015. - 354 с.

19. Conditioning 3D object - based models to dense well data / Y.C. Wang, M.J. Pyrcs, 0. Catuneanu, J.B. Boisvert // Computers \& Geosciences. - 2018. - V. 115. - P. 1-11.

20. Основы трехмерного цифрового геологического моделирования / К.В. Абабков, Д.Д. Сулейманов, Ш.Х. Султанов, Ю.А., Котенев Д.И.: Варламов. - Уфа: Нефтегазовое дело, 2010. -199 c.

Поступила 24.04.2019 2.

\section{Информация об авторах}

Казанская Д.А., аспирант Тюменского Индустриального Университета.

Александров В.M., кандидат геолого-минералогических наук, доцент кафедры геологии Тюменского Индустриального Университета; заместитель генерального директора по геологии АО «Тандем».

Белкина В.A., кандидат физико-математических наук, доцент кафедры геологии нефти и газа Тюменского Индустриального Университета. 


\title{
GEOLOGICAL MODELLING OF VIKULOVSKAYA SUITE PRODUCTION DEPOSITS
}

\author{
Diana A. Kazanskaya', \\ kazanskaya_d@aotandem.ru \\ Vadim M. Alexandrov $\mathbf{V}^{12}$, \\ alexandrov_v@aotandem.ru \\ Valentina A. Belkina', \\ belkinava@tyuiu.ru \\ 1 Tyumen Industrial University, \\ 38, Volodarsky street, Tyumen, 625000, Russia. \\ 2 «Tandem», \\ 57, Respubliki street, Tyumen, Russia.
}

The relevance. The tasks of researching, exploring, assessing oil and gas, designing, field developing are solved on the basis of geological models. Along with the fact that modern geological modelling allows obtaining three-dimensional descriptions of deposit, studying the character and variability of parameters of the formation and fluids saturated it, it allows as well estimating the uncertainties that inevitably arise in geological modelling of the formation. Thus, the accuracy of the solution of any geological problem is mainly determined by the adequacy of the three-dimensional model of the object. It is necessary to involve in addition to empirical data all kinds of indirect information in geological model. It is necessary to study sedimentation in time and space for detailed prediction of the size and shape of the reservoir, the distribution of zones of improved reservoir and correct construction of the geological model.

The main aim of the research is to improve the methods of geological three-dimensional modelling taking into account the conditions of sedimentation. This is caused by the fact that the lithofacial characteristics of production deposits are the main factors of heterogeneity of reservoir and oil-saturation of reservoirs. The technique that takes into account the facial structure of deposits allows constructing a discrete-continuous three-dimensional geological model, which describes correctly the geological object under study and has significantly higher prognostic properties.

Objects: vikulovskaya suite production deposits of Em-Egovskii licensed precinct.

Methods: detail well correlation, improved electrometric method of facial diagnostic, deterministic and stochastic methods of double dimensional and three-dimensional geological modelling.

Results. The authors have constructed the facial model by the core and GRW data, based on the improved technique of V.S. Muromtsev. The facial model includes the following facies groups: far beach area, transition beach area and pre-frontal beach area. A detailed correlation was carried out with the data of the new 192 wells. Three sedimentation cycles were distinguished within the formation VK1, according to the results of correlation. This cycles are characterized by a good consistency in the area. Based on more accurate seismic data and new wells data using sedimentation conditions the authors developed the refined model of vikulovskaya suite production deposits of Em-Egovskoe field. The geological structure of vikulovskaya suite production deposits has changed greatly according to the constructed model. External testing confirmed high accuracy and high prognostic properties of the developed geological model. The area of the deposits, oil-saturated thickness of the deposit and geological reserves have decreased according to the updated structure. The refinement and detailing of the formation structure will improve the efficiency of additional exploration of poorly studied parts and development. The proposed model of VK deposits is used to create a hydrodynamic model and to justify the most effective geological and technical measures.

\section{Key words:}

Seismic data, core, geophysical well research data, well correlation, conceptual model, geological model, vikulovskaya suite, deposit.

\section{REFERENCES}

1. Zaboeva A.A. Razrabotka metodik trekhmernogo geomodelirova nya $v$ usloviyakh neodnorodnosti i neravnomernosti geologo-geofi zicheskoy informatsii (na primere mestorogdeny Zapadnoy Sibiri). Dis. Kand. nauk [Development of three-dimensional modeling techniques in terms of heterogeneity and irregularity of geological and geophysical information (on the example of West Siberia deposits). Cand. Diss.]. Tyumen, 2012. 167 p.

2. Deutsch C.V. Geostatistical reservoir modeling. New York, Oxford University Press, 2002. $376 \mathrm{p}$.

3. Belkina V.A., Bembel S.R., Zaboeva A.A., Sankova N.V. Osnovy geologicheskogo modelirovaniya (Ch. 1) [Fundamentals of geological modeling (P. 1)]. Tyumen, Tyumen of Oil and Gas State University, 2015. $168 \mathrm{p}$.

4. Martin R., Boisvert J.B. Towards justifying unsupervised stationary decisions geostatistical modeling: Ensemble spatial and multivariate clustering with geomodeling specific clustering metrics. Computers \& Geosciences, 2018, vol. 120, pp. 82-96.
5. Stochastic Modeling and Geostatistics. Principles, Methods, and Case Studies (AAPG Computer Applications in Geology, No. 3). Eds. J.M. Yarus, R.L. Chambers. Tulsa, Oklahoma: AAPG, 1994. 379 p.

6. Rostovtsev N.N. Stratigraficeskiy slovar mezozoiskikh i kaynozoiskikh otlozheniy Zapadno-sibirskoy nizmennosti [Stratigraphic Dictionary of the Mesozoic and Cenozoic lowlands of West Siberia]. Leningrad, Nedra Publ., 1978. 183 p.

7. Geologicheskoe stroenie i perspektivy neftegazonosnosti ZapadnoSibirskoy nizmennosti [Geological structure and oil and gas potential of the West Siberia lowlands]. Ed. by N.N. Rostovtsev. Moscow, Gosgeologtehizdat Publ., 1958. 391 p.

8. Karagodin Yu.N. Neft i gaz vikulovskoy svity [Oil and gas of Vikulovskaya suite]. Nauka $v$ Sibiri, 2008, no. 41, pp. 10-13.

9. Aleksandrov V.M., Kazanskaya D.A., Belkina V.A. Geneticheskaya klassifikatsiya tempestitov [Genetic classification of tempestites]. Territorya Neftegaz, 2014, no. 6, pp. 40-43.

10. Aleksandrov V.M., Kazanskaya D.A., Belkina V.A. Osobennosti formirovanya tempestitov v otlozhenyakh vikulovskoy svity [Fe- 
atures of formation of tempestites in the deposits of the Vikulovskaya suite]. Neft i gaz, 2015, no. 5, pp. 10-15.

11. Reineck H.-E., Singh I.B. Clastic sedimentation. Translated from English. Moscow, Nedra Publ., 1990. 352 p.

12. Selly R.C. Applied Sedimentology $\left(2^{\text {nd }}\right.$ ed.). San Diego, Elsevier, $2000.523 \mathrm{p}$.

13. Reading H.G., Collinson J.D. Clastic coasts. Sedimentary Environments: processes, facies and stratigraphy. $3^{\text {rd }}$ ed. Ed. by H.G. Reading. Oxford, Wiley Blackwell, 1996. 704 p.

14. Zhanglin Li, Xianin Zhang, Clarke K.C., Gang Liu, Rui Zhu. An automatic variogram modeling method with high reliability fitness and estimates. Computers \& Geosciences, 2018, vol. 120, pp. 48-59.

15. Kontorovich A.E., Ershov S.V., Kazanenkov V.A., Karogodin Yu.N., Kontorovich V.A., Lebedeva N.K., Nikitenko B.L., Popova N.I., Shurigin B.N. Paleografia Zapadno-Sibirskogo osadochnogo basseina v melovom periode [Paleography of the West Siberia sedimentary basin in the Cretaceous period]. Geologiya $i$ geofizika, 2014, vol. 55, no. 5-6, pp. 745-776.

16. Zakrevsky K.E. Praktikum po geologicheskomy 3D-modelirovaniyu. Postroenie testovoy modeli v Petrel 2011 [Workshop on geolo- gical 3D modeling. Building a test model in Petrel 2011]. Mosscow, 2012. $114 \mathrm{p}$.

17. Strukova O.V., Zakrevsky K.E. Geologicheskoe modelirovanie v RMS. Prakticheskie uprazhgneniya. 2 D i 3D modelirovanie [Geological modeling in RMS. Practical exercises. 2D and 3D modeling]. Mosoc, ROXAR Publ., 2012. 694 p.

18. Belozerov B.V., Butorin A.V., Gerasimenko P.N., Zhuravleva E.V., Faizov R.Z. Prakticheskie sovety po 3D geologicheskomu modelirovaniyu [Practical tips on 3D geological modeling]. St. Petersburg, Gazpromneft NTC Publ., 2015. 354 p.

19. Wang Y.C., Pyrcs M.J., Catuneanu O., Boisvert J.B. Conditioning $3 \mathrm{D}$ object - based models to dense well data. Computers \& Geosciences, 2018, vol. 115, pp. 1-11.

20. Ababkov K.V., Suleymanov D.D., Sultanov Sh.Kh., Kotenev Yu.A., Varlamov D.I. Osnovy trekhmernogo tsifrovogo geologicheskogo modelirovanya [Fundamentals of three-dimensional digital geological modeling]. Ufa, Oil and Gas Business Publ., 2010. 199 p.

Received: 24 April 2019.

\section{Information about the authors}

Diana A. Kazanskaya, postgraduate student, Tyumen Industrial University.

Vadim M. Alexandrov, Cand. Sc., associate professor, Tyumen Industrial University.

Valentina A. Belkina, Cand. Sc., associate professor, Tyumen Industrial University. 